Revista Eletrônica do Mestrado

Profissional em Administração da UnP

\title{
edUnp
}

V. 10, N. 3, 2018

ISSN 1984-4204

https://repositorio.unp.br/index.php/raunp

https://doi.org/10.21714/raunp.v10i3.1837

\section{Innovation management: the degree of innovation in the COREDE Production metal mechanic sector, Brazil}

\section{Gestão da inovação: o grau inovativo no setor metal mecânico do COREDE Produção, Brasil}

\author{
Adrieli Alves Pereira Radaelli ${ }^{\mathrm{a}}$, Cassiane Chais ${ }^{\mathrm{b}}$, Oberdan Teles da Silva ${ }^{\mathrm{c}}$, François Coallier ${ }^{\mathrm{d}}$, Eric Charles \\ Henri Dorion ${ }^{\mathrm{e}}$, Joel Tshibamba Mukendi ${ }^{\mathrm{f}}$
}

\begin{abstract}
${ }^{a}$ Mestre em Administração. Universidade de Caxias do Sul (UCS). Programa de Pós-Graduação em Administração (PPGA). adrieli. radaelli@gmail.com

${ }^{\text {b} M e s t r e ~ e m ~ A d m i n i s t r a c ̧ a ̃ o . ~ U n i v e r s i d a d e ~ d e ~ C a x i a s ~ d o ~ S u l ~(U C S) . ~ P r o g r a m a ~ d e ~ P o ́ s-G r a d u a c ̧ a ̃ o ~ e m ~ A d m i n i s t r a c ̧ a ̃ o ~(P P G A) . ~}$ cassichais@gmail.com

'Doutor em Administração. Universidade de Caxias do Sul (UCS). Programa de Pós-Graduação em Administração (PPGA). oberdanteles@hotmail.com

${ }^{\mathrm{d} D o c t o r}$ in Electrical Engineering. École de Technologie Supérieure (ÉTS). francois.coallier@etsmtl.ca

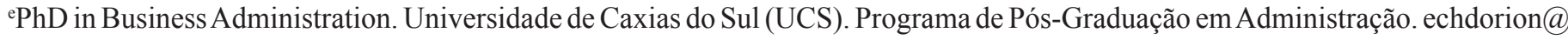
gmail.com

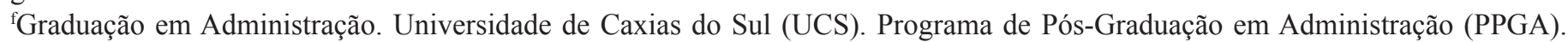
tshibambajoel@yahoo.fr
\end{abstract}

\begin{abstract}
This study aimed to identify the degree of innovation in the COREDE Production metal-mechanic organisations, in the State of Rio Grande do Sul, through the application of an innovation audit. This study was conducted from data provided by the University of Passo Fundo, through the 'Productive Extension and Innovation' project. A survey was performed in a sample of eight respondent companies. The data was analyzed through a descriptive statistical analysis method, which identified the individual and collective innovative aspects of the metal-mechanic sector. The results show that that companies need to pay attention to the factors that cover the processes, as they depend on the good development of the goals and objectives of the organisation, as well as the management and development of new products.
\end{abstract}

Keywords: Innovation Management; Innovation Audit; Degree of Innovation; Metal-mechanic sector; COREDE production; Brazil.

\begin{abstract}
Resumo
Este estudo objetivou identificar o grau de inovação das organizações no Estado do Rio Grande do Sul por meio da aplicação de uma auditoria da inovação em organizações do COREDE Produção, no estado do Rio Grande do Sul. Este estudo foi realizado a partir dos dados disponibilizados pela Universidade de Passo Fundo, através do projeto extensão produtiva e inovação. Para tanto, foi realizada uma pesquisa survey com uma amostra de oito empresas respondentes a qual foi analisada utilizando-se a análise estatística descritiva na qual permitiu identificar o grau inovativo individual e coletivo do setor em estudo. Conclui-se, com base nos resultados obtidos, que as empresas precisam dispender atenção aos fatores que abrangem os processos, pois deles dependem o bom desenvolvimento das metas e objetivos da organização, bem como o gerenciamento e desenvolvimento de novos produtos.
\end{abstract}

Palavras-chave: Gestão da Inovação; Auditoria de inovação; Grau de inovação; Setor metal mecânico; COREDE production; Brasil. 


\section{Introduction}

The competitiveness between industries and organisations becomes more intense given to the fragmentation and the volatility of the market. Thus, the organisations seek to maximize the value offer to their clients by consolidating their positioning from their strategy (Ahlstrand et al., 2001). These organisations, with respect to maximize the value offer and to reduce transaction costs, seek profitability and sustainability. However, such elements are the consequence of a business model based on the quest for radical or incremental innovation (Porter, 1990). For Schumpeter (1997), the concept of innovation is the pursuit of economic development that creates distinctive competitive organisations, where they represent one of the contemporary economics key driving forces behind competitive advantages and have become socioeconomic category of their own (Batraga et al., 2019) .

Innovation is a key concept that guide, support and strengthen the organisations. For Tidd, Bessant and Pavitt (2008), the innovation process stems from a pattern that includes the search for new facts, its selection and implementation, where an organisation's performance increases when such factors are sought through time. Innovation involves competitive elimination from older to newer processes and demand based recombination processes that generate financial value to stakeholders through new devices and new uses. Innovation thus stems from new techniques, new processes, absorption capacity of new demands and the creation and generation of new opportunities that are not explicit in the market (Schumpeter, 1997; Ahlstrand et al., 2001).

Thus, innovation takes an intentional and prescriptive character in the organisations and should be managed from the perspective of performance indicators, whether subjective or tangible. Consequently, it needs to be managed using the proper metrics, and thus with an understanfing of the elements to be measured (Mintzberg, 1989). Metrics have been used in key researches to identify innovations and its diffusion (De Prato, Nepelski, \& Piroli, 2015). The objective of this study is to identify the degree of innovation of the organisations of the metal-mechanic sector in the State of Rio Grande do Sul, Brasil.

\section{Innovation audit}

Audit tools allow an organisation to understand and base its forecasting and planning actities with more accuracy. The audit tool developed by Tidd et al. (2008) aims to measure the innovation performance of organisations and to demonstrate how the organisations develop their innovation processes, through behaviour patterns on innovation. The strengths of the tool is its measurement strategy based on certain areas of the organisation that need to be optimized. The model demonstrates the factors that lead to failure and organizational success, as well as the processes that need to be improved. The model explains how the innovative processes occur in a particular organisation. It offers a list of aspects to be verified on a constant basis and proposes benchmarking activities, which serves as a permanent guide for innovation improvement.

An organisational innovation system must precisely measure outputs, through the number of new artifacts produced, success indicators of product innovation, number of scientific patents and jobs. It must evaluate the strategic success results of measurement, such as increased profitability, adding value, market share, and revenue growth. It must provide operating results measurement, such as the identification of improvements in quality and flexibility, and customer satisfaction survey. In addition, measurement must compare competitive sectors activity results, by exemplifying quality, cost of production, market share and others. It can also be 
used for learning providing insight for new designs, or pointing out specific subsystems problems (Ahlstrand et al., 2001).

\subsection{Strategy}

Strategies can be classified as classical, modern and postmodern. The classic one refers to the prescriptive strategy, referred as the "the best way" toward the establishment of know-how and where the "know why" is exclusive (Volberda, 2004). It is a process that has a top to bottom logic. Its character is analytic, involving rationality and orthodoxy. The theory proposed by Porter, Newman, Ansoff, Selznick, Andrews, Chandler, Christensen, Guth and others is based on both the cybernetics and the contingency theories of industrial organisations. For Volberda (2004), the classic approach is defined by a prescriptive and Cartesian approach, where prospective plan are elaborated and then implemented.

The modern and postmodern strategies are derived from the cognitive, complex, behavioral, and learning theories, where organizational success depends on the organisation itself and its endogenous factors. They define the organisation, through an inside-out configuration, by having a proactive and anticipatory culture. It describes strategy as a descriptive process that focus on "how to get there", which contradicts the perfect rationality developed by the classical current (Ansoff, DeClerck, \& Hayes, 1981). The goal, from this configuration, is to make the organizational actions to determine to the other competitors the adequate action (Volberda, 2004).

Steensen (2014) identified three basic perceptions of the organizational strategy. The strategy perceived as a communication process, which passes external information and the actions of the organisation to its members; the intentional strategy, where there is sharing in development and future path. Finally, the realization strategy, where the actions of the each member of the organisation is recognized and evaluated through its activities and decisions.

Thus, strategy involves both rational, objective, subjective, and intangible elements. In this conception of strategy, the work of Hax and Majluf (1986) represents an explicit intention of the organisation. It involves a social, political and cognitive process that is developed in structures of reference. They emphasize on the importance of social conversion to optimize the organisation's distinctive competence to generate competitive advantage. The importance of the human factor in the process of structuring and executing the strategy is brought by Ansoff (1990), which enhances the importance of the relationship between the subjects and the organisation. The author recalls that the concept of organisation involves both a production agency and the definition of a social agent.

The effect of the strategy is the top result when compared to the competition. This understanding of competitive advantage is brough up by Hitt, Ireland and Hoskisson (2002) and pointed out by Teece (2010); who mention that a strategy is part of a business models, representing an operating structure and a strategic framework. Porter (1990) suggests a prescriptive strategy, which points out that a strategy involves a consolidated and a competitive position. The author refers to cost differentiation or combination as a starting point of an organisation to defend its competitive market forces.

In terms of organizational strategy, the issues that constitute the audit tool of Tidd et al. (2008) aim to demonstrate if an organisation fosters innovative ideas with an innovation perspective. A prescriptive strategy uses an audit tool that aims to identify if the innovation strategy is explicit and clear, and known by everyone in the organisation. The tool must also identify whether the employees know what the organisation's 
competences are and whether the organisation has the ability to predict future threats and opportunities. Concerning competencies, the tool refers to the process of the descriptive strategy, typical of the endogenous elements of the firm. The questions related to the innovation strategy also aim to identify if the organisation fosters a shared vision and if it is deployed within the firm hierarchical support. It also seeks to identify if there is symmetry between innovation projects and the overall strategy of the organisation.

\subsection{Process}

Process management is a strategic management approach that addresses the management policies, methods and practices used to coordinate and govern business processes (Prajogo et al., 2018). The processes assume operational and strategic character, where the basic "control activity" in a management process is related to the uncertainties that alter the performance of a certain organizational plan (Ballou, 2006). Thus, a process involves monitoring elements that lead to a plan deviation. The processes must have the managerial capacity to adapt, therefore to enhance anticipation and the necessary adjustments capacity to unplanned changes. In addition, processes act in favor of goals and objectives, promoting outputs in terms of performance reports as well as promoting corrective actions.

For Tidd et al. (2008) the process of innovation is based on search, selection and implementation activities. The "search activity" refers to the analysis of an internal and external scenario as well as the signals regarding the threats and opportunities. The "selection activity" involves deciding on what are the strategic signs for an organisation. The "implementation activity" refers to the implementation of an idea into practice. Importantly, according to the authors, the search, selection and implementation activities are improved over time, therefore, expose a correlation between process performance and time. Furthermore, the authors, in their audit on innovation, aim to identify if an organisation has implemented a process that assists in the development of new products and, if the innovation projects that are developed are related to the customers needs. Finally, the tool also seeks to explain the change management mechanisms from an idea to its implementation and, whether all the participating departments.

In a systemic perspective, process management involves an integration of departments into a horizontal chain (Maximiano, 2012). This horizontal model integrates several endogenous functions of the organisation, which facilitates the solution of the constraints and, which increases the efficiency and the effectiveness of an organisation. Managing processes in a horizontal format makes the organisation work with a common purpose with measurable performance indicators, whether operational or strategic, and may facilitate the introduction of innovative policies. However, this involves modifying an organizational culture over a period (Betim, 2018).

The process of generating innovation implies in the improvement of scientific and technological capacities and focus on the process of self-learning, as well as in the production and commercialization process. Its focus is toward new solutions or ideas generation for processes and products development, and undoubtedly in the interaction of agents such as suppliers, clients, universities and research centers (Lundvall \& Johnson, 2000; Betim, 2018).

\subsection{Organisation}

According to OECD (2005), the concept of innovation can be organizational, product, process and marketing. Drucker (1999) states that the innovative organisation is one that systematically applies a certain 
knowledge to generate the production of new knowledge. It also states that the innovative organisations are the recreation of business involving resources, subjects and activities. For Whitley (2000), the innovative organisations are the one that operate with a degree of uncertainty, by promoting reconfiguration routines and capabilities. Remember that this flexibility typical of innovative organisations arises due to the adaptation of patterns of change and anticipation of future demands. It also stresses that the degree of uncertainty in innovation changes organizational processes that generate new artifacts for new uses making the company get hold of revenue (Whitley, 2000; Teece, 2010; Johannessen, 2013).

According to Tidd et al. (2008), the innovative organisation is one that has in its structure shared vision, leadership and desire to innovate, teamwork, creative environment and learning ability. Regarding innovative organisation, the authors assert the importance of extensive communication. For them is communication is key to a culture of innovation should be encouraged in every way, be it upward, downward and sideways. Regarding the organisation, in its innovation audit tool, Tidd et al. (2008), are intended to identify whether the company is structured to develop innovation and actors working in independent interaction of the department. The objective is to identify whether there is a structure within the organisation to facilitate the decisionmaking team and organizational communication develops in every way promoting a climate for generating new ideas.

According to Teece (2010), the concept of business model involves two endogenous structures and in order to achieve innovation, it is necessary to systematically plan it within the structure of the organisation. The first refers to an operational structure that relates to revenue and expenditure. The second has a strategic connotation. When integrated together, they generate value to customers. Johannssen (2013) postulates that when a company puts innovation ahead in its new business models, it will influence developing new methods and techniques aimed at reducing complexity and generating revenue growth and increased value for stakeholders.

\subsection{Relationships}

According to Grönroos (2000), interaction and networking practices in relation to relationship management have arisen in Sweden through the research developed by the IMP Group, a school of marketing thinking that emphasizes the importance of relationships in business networks. The Swedish school proposes a network model according to which the elements that compose it involve actors, activities and resources. It establishes among them a degree of interdependence. The quality of the relationship and the practices collaboration between the organisations influences performance (Pereira, 2004).

One factor that can influence an organisation's innovative activity is its organizational relationships. These relationships can occur in a variety of ways, such as: the search for market power, access to new markets and even the development of new products. In order to explore the possibilities of open innovation through interorganizational relationships, it is necessary to implement coordination mechanisms that optimize the results of these partnerships, since the greater the interaction and the heterogeneity of knowledge among the partners the greater the chance that innovation will occur (Baggio et al., 2018).

A relationship between organizational partners promotes cost reduction and extends service improvement through common objectives on a long-term relational basis (Resende, Mendonça, \& Araújo, 2005). However, according to Carona and Csillag (2006), the concept of relationship can become strategic when it is broadened through mutual trust and collaboration between the actors and agents involved in the 
process. In addition, a relationship between the actors and the organisations can effectively result in innovation and learning (Humphrey \& Schmitz, 2000).

For Fan, Tsai and Lin (2010) relationships take a strategic character. When analyzed in optic network lead to learning given the complementary expertise between the partners. For them, relationships have a history as the capital and in effect the performance. Remember, however, the need for routines socializing and interpret the collective knowledge of the relationship between partners. So the relationships when converge routines produce common knowledge and expand the capacity for knowledge absorption. On the other hand, these routines can broaden the scope of knowledge.

Tidd et al. (2008) postulate that management of innovation involves relationships between partners. The authors establish a typology of interactions that occur with product interaction, where products and services interact with each other by adapting and evolving mutually. The process interactions occur when the network interactions concern product and process interdependencies. The social interactions within the organisation involve interactions between skills and knowledge in the development of internal processes and products. The social interactions between the organisations lead to systemic innovations.

But, the authors warn that a network processes combination will generate a "chain of transactions" that can limit the capacity of change management, beacause of the lack of flexibility of the processes. In terms of relationship, the audit proposed by Tidd et al. (2008) aims to identify if an organisation interacts with its suppliers, clients and universities, to leverage knowledge and the development of new concepts. It also intends to characterize if there is proximity between the company and its local and national partners and, if there is collaboration with supplier in the development of new products and processes.

\subsection{Learning}

By the end of the XXth century, still little research has been done on the complexity of human nature and learning (Spender, 1996). The author postulates that knowledge is developed in subjective structures, being a resources optimization process, where knowledge is inserted in the company through the reflection and the cognitive ability of the actors. According to the author, knowledge involves a dialectic between the "self" and the "social", where redundancy contributes to double-loop learning and underlies interpretive flexibility. Knowledge is systemic when individual skills become collective and feedback occurs. As far as the social element is concerned, Spender emphasizes that knowledge is a public good that does not depreciate over time; being transferred from one person to another, through routines and norms. Finally, knowledge is based either on rationality (experience-information) or on empiricism (reason-rigorous managerial analysis) (Nonaka \& Takeuchi, 1995; Spender, 1996).

For Grant (1996), knowledge must be applied in an organisation to generate value. To occur, it is necessary that the transfered knowledge refers to know how (tacit, procedural) and know about (declarative, explicit, public). According to the author, it is necessary that knowledge possesses an aggregation capacity, and an absorbing organizational capacity. Knowledge plays a fundamental role in changing routines, norms and organizational values, to avoid the consequences of reification. The knowledge-based view should aim at coordinating specialists, through the resolution of intra-organizational goal conflicts (Nonaka \& Takeuchi, 1995; Grant, 1996).

For Nonaka and Toyama (2002), organizational knowledge involves the conversion of explicit-tacit knowledge. The authors assert that it involves the division of tacit knowledge by direct experience, the articulation 
of tactical knowledge through dialogue and reflection, the systematization of explicit knowledge, learning and acquisition of new tactical knowledge. They point out, however, that the promotion of organizational learning involves justification and interaction costs, and the necessary condition for the rate of knowledge conversion depends on the organizational capacity of synthesis.

For Tidd et al. (2008), knowledge management strategies can be ondulatory, integrated, deployed, transposed and transfered. The ondulatory concept represents a bottom-up knowledge fomented process. The Integration represents the functional knowledge that occurs within the interface improvements processes. The strategy of knowledge deployment is the union of processes, services and systems, such as enterprise resource planning. The transposition concept represents new knowledge that occurs through a new combination of skills that the organisation already has. The transfer concept refers to the development of a different context and already existing knowledge. In a learning perspective, the authors point out that these concepts depend on the organisation's intention, transparency and receptivity. For the authors it is necessary that a company demonstrates an explicit intention of generating transferable knowledge and the capacity to receive and implement such knowledge (Tidd, Bessant \& Pavitt, 2008).

Learning can be considered as a dynamic process that allows changes from existing individual and organizational knowledges. These changes may occur through understanding or decisional changes, when new learned knowledge interferes with action (Betim, 2018). The innovation audit of Tidd et al. (2008) seeks to verify if the organisation is committed to the development of collaborators, allowing it to learn from its own mistakes. It also aims to verify if the company compares its products and processes with others by prioritizing the exchanges and experiences with other organisations to achieve continuous learning. In such perspective, a company acquires the capacity to measure improvement points in terms of innovation management.

\subsection{Productive extension of design and innovation}

The Productive Extension and Innovation (PEPI) project is a partnership between the universities of the State of Rio Grande do Sul and the State Government (AGDI). PEPI is headquartered at the University of Passo Fundo (UPF) and is currently coordinated by the UPF Science and Technology Exchange Division, the UPFTec (UPFTEC, 2015). The university has more than 300 research projects, more than 50 undergraduate courses and more than 30 post-graduate professional courses, $15 \mathrm{MSc}$ and $6 \mathrm{PhD}$ programs. PEPI is located in a region geared by industrial production, which requires technological innovations for value added and market gains. The region offers a strategic environment of knowledge (academy) and products (enterprises), which fundamental in an innovation development process (UPF, 2015).

The project aims to increase companies' efficiency and competitiveness, increased production, employment and income, as a means for the development of economic sectors and regional clusters. At the same time, it has the scope to improve the businesses of investment culture and the search for innovation, technology and knowledge by the UPF, technological and research centers, in addition to improving the ability of the University to meet the real needs of companies. They can participate in the Productive Extension Project and Innovation companies based in the municipalities belonging to COREDE Production (UPFTEC, 2015).

The management team includes a coordinator and six outreach students. They are responsible for promoting release of forums in partnership with the municipalities located in the region, in order to publicize the project and sensitize companies to their commitment and adherence (Governo do Estado do Rio Grande do Sul, 2015; UPFTEC, 2015). 
By the time a company shows interest in joining the project, the company receives a visit from an outreach student, a learning professional dedicated to supporting and empowering companies operating in priority sectors of the region. The PEPI policy is to assist the companies in identifying opportunities, proposing solutions and improvements (Governo do Estado do Rio Grande do Sul, 2015).

\section{Method}

A population of 20 companies from the metal-mechanic sector in the State of Rio Grande do Sul was selected for this research. The data bank came from the PEPI database. Eight companies were selected by the project coordinator at the University to compose the sample. This selection took place from the participation and the fulfillment of the activities of each of them. The questionnaire that measures the innovative degree follows the audit based model of Tidd, Bessant and Pavitt (2008) (Annex 1).

The tool uses the concept of strategy, processes, organisation, relationships and learning to calculate the innovative degree of the companies. The questionnaire included 40 questions in an optional Lickert scale, from 1 to 7, were one (1) and seven (7) respectively means "definitely false" and "very true". The research is characterized as exploratory, including a quantitative approach and procedure. The data is sorted without the interference of the researcher and collected through questionnaires (Pestana \& Gageiro, 2005).

The primairy data used for this study comes from field research with the 20 companies and the secondary data comes from the literature review and the PEPI files (Gibbs, 2009). Data collection was made through a Google Docs tool, with an adapted structured questionnaire from Tidd et al. (2008). A questionnaire was sent to the participating companies via E-mail. Descriptive statistical techniques were used to characterize the selected sample for the test results. According to Sampieri, Collado and Lucius (1998), a descriptive study must measure and display a phenomenon that manifests itself in certain situations or events.

\section{Results}

Through data analysis, it was possible to identify how the companies that participated in the survey adopted management of innovation practices. Thus, it was possible to evaluate these organisations through the tool used by Tidd et al. (2008), the Innovation Radar, which group the results in five areas: strategy, processes, organisation, relationships and learning.

It is possible to observe that the "company 1" stands out presenting the final average of all the factors of 5.08. However, the company with the lowest average is "company 8 ", with 3.75 , which makes the company less innovative, according to data, as presented in Table 1.

Tabela 01

Innovation Management Audit results in PEPI's Participating Companies

\begin{tabular}{|c|c|c|c|c|c|c|}
\hline Companies & Strategy & Processes & Organisation & Relationships & Learning & $\begin{array}{c}\text { Companies } \\
\text { Avarege }\end{array}$ \\
\hline 1 & 4.63 & 5.13 & 4.75 & 5.63 & 5.25 & 5.08 \\
\hline 2 & 4.50 & 3.75 & 4.38 & 5.00 & 4.25 & 4.38 \\
\hline 3 & 3.88 & 3.88 & 3.63 & 5.25 & 4.13 & 4.15 \\
\hline 4 & 3.50 & 3.38 & 5.50 & 3.75 & 4.75 & 4.18 \\
\hline 5 & 5.00 & 4.38 & 4.38 & 5.75 & 5.25 & 4.95 \\
\hline 6 & 3.88 & 4.13 & 4.50 & 4.88 & 4.75 & 4.43 \\
\hline 7 & 3.50 & 4.13 & 4.13 & 4.38 & 4.88 & 4.20 \\
\hline 8 & 3.00 & 3.50 & 3.88 & 4.38 & 4.00 & 3.75 \\
\hline
\end{tabular}




\begin{tabular}{llllll}
\hline $\begin{array}{c}\text { Factors } \\
\text { Avarege }\end{array}$ & 3.98 & 4.03 & 4.39 & 4.88 & 4.66 \\
\hline
\end{tabular}

Source: Survey data (2016).

A graphic presentation of data gives a more comprehensive analysis. Figure 1 shows that "company 1 " develops factor relationships, with an average of 5.08 or $80.43 \%$ of effectiveness. According to Tidd et al. (2008), the relationship factor in innovation management aims to identify whether there is interaction between the organisation with suppliers, customers and universities, thus enhancing knowledge and developing new concepts.

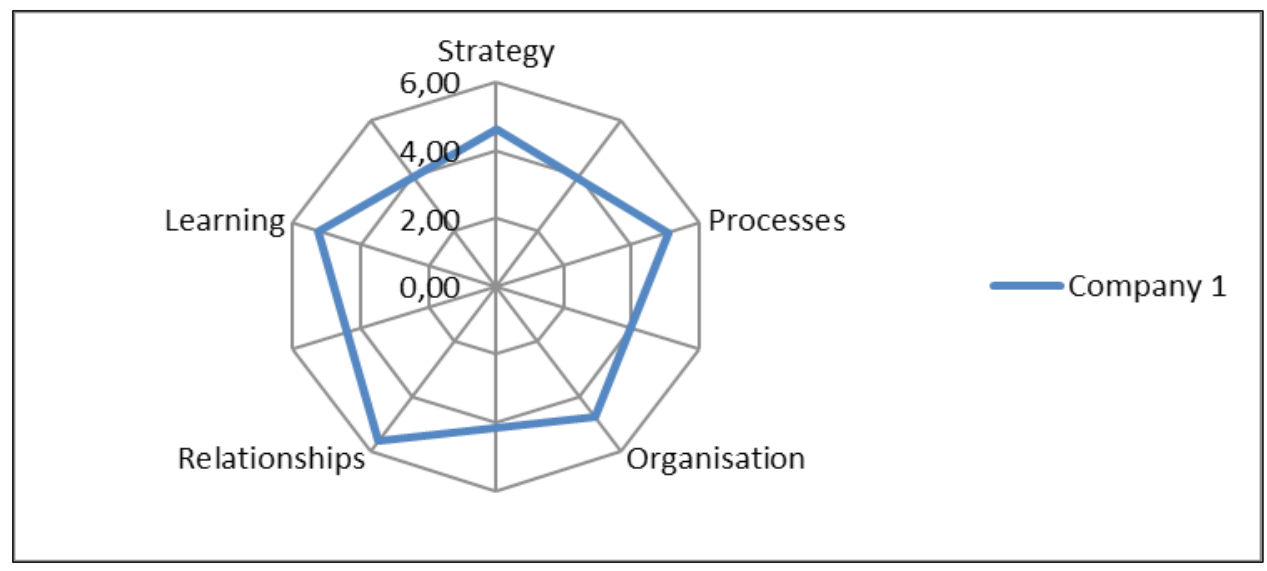

Fig. 1. Company 1 data Source: Survey data (2016)

Figure 2 shows the results of Company 2, which present a low average in the factor processes of 3.75 . It demonstrates that the company does not have a process to assist in the development of new products, since no project is being developed within the deadline as proposed by Tidd et al. (2008). However, Company 2 has an average 5 in "relationships", representing $71.43 \%$ of effectiveness and indicating that it interacts with its suppliers, customers and also with universities.

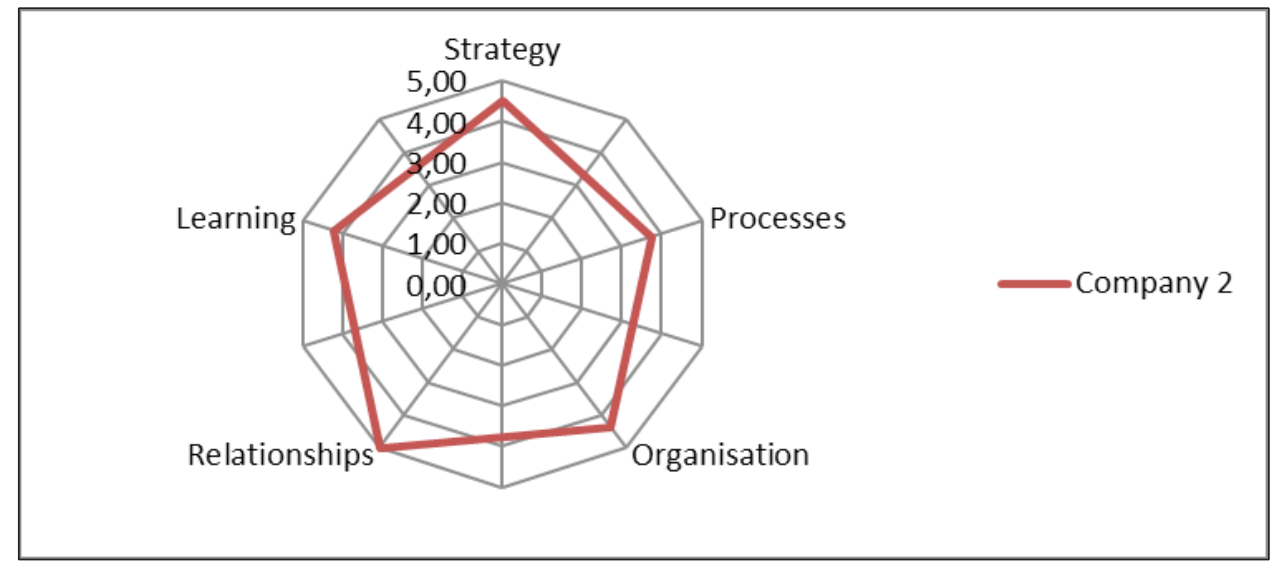

Fig. 2. Company 2 data

Source: Survey data (2016)

Company 3 shows three factors with average 3, being strategy, processes and organisation, corresponding to $42.86 \%$ (Figure 3 ). This shows that the company does not have and does not follow a definite plan, since it is not structured to develop innovation and the actors do not work in independent interaction of the organizational 
department, as suggested by on Tidd et al (2008).

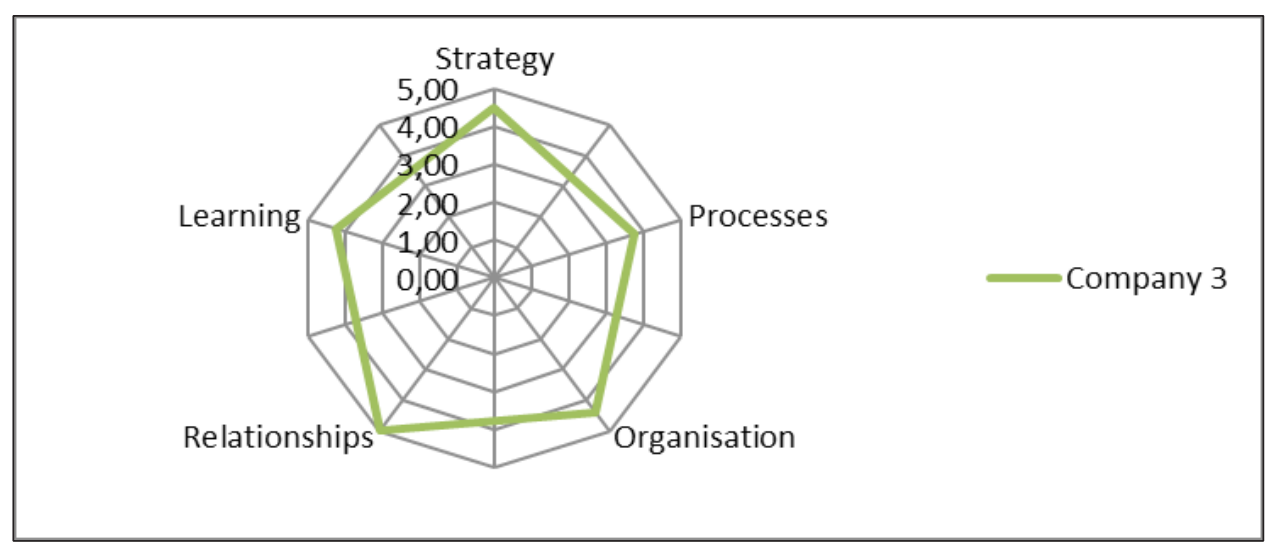

Fig. 3. Company 3 data Source: Survey data (2016)

Company 4 shows an average of 5.50 or $78.57 \%$ of its effectiveness. This result demonstrates that the company is well organized, with an organizational structure that favors the development of innovation and integration of the actors together. Moreover, the process factor shows an average of 3.38, which is relatively low and it indicates that does not have well-defined processes (Figure 4).

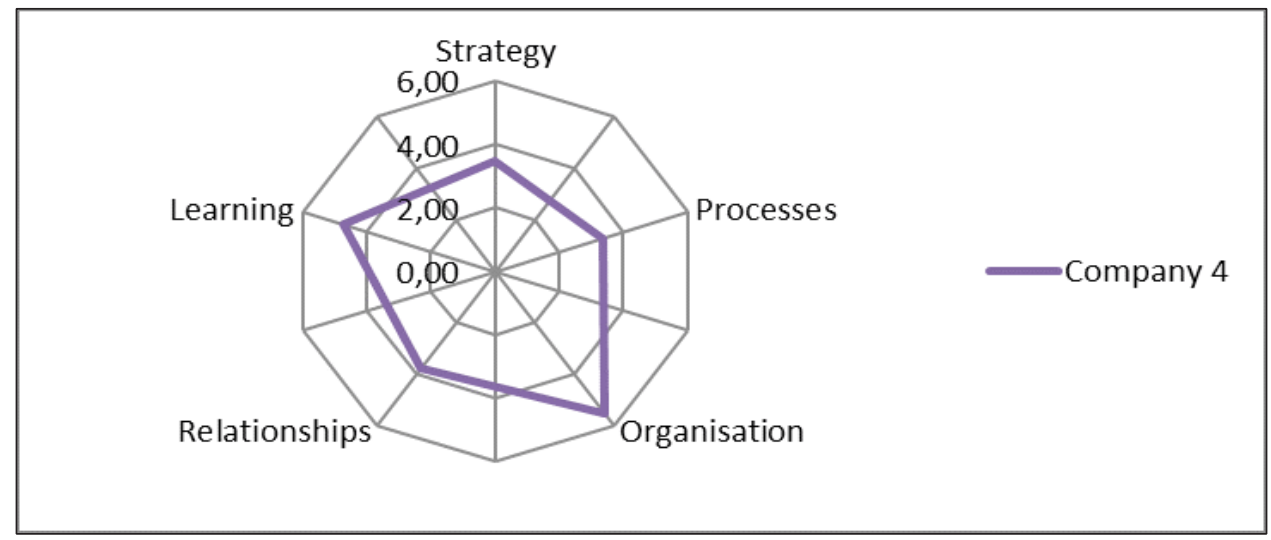

Fig. 4. Company 4 data Source: Survey data (2016)

Company 5 obtained average results above 5 points, or $71.43 \%$ of efficicency on three factors, strategy, relationships and learning, reaching 5.75 in factor for "relationships" (Figure 5). This result demonstrates a priority of the company to foster innovative ideas, in order to boost innovation, to strengthen the interaction between the employees involved with the organisation's routines, their development, causing the organisation to learn from their own errors, as suggested by Tidd et al. (2008). 


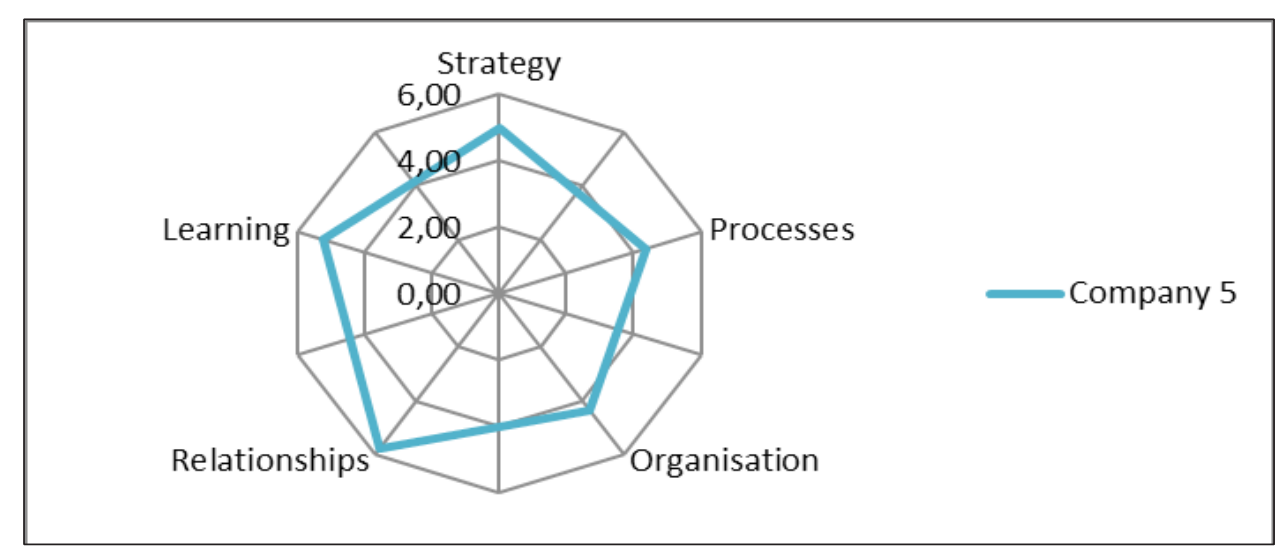

Fig. 5. Company 5 data

Source: Survey data (2016)

The data of the Company 6 shows averages of 4 were in four factors, namely process, organisation, relationships and learning. For the strategy factor, the company has an average of 3.88 or $55.43 \%$ of maximization. This demonstrates that the company works in a balanced manner in relation with all the factors (Figure 6).

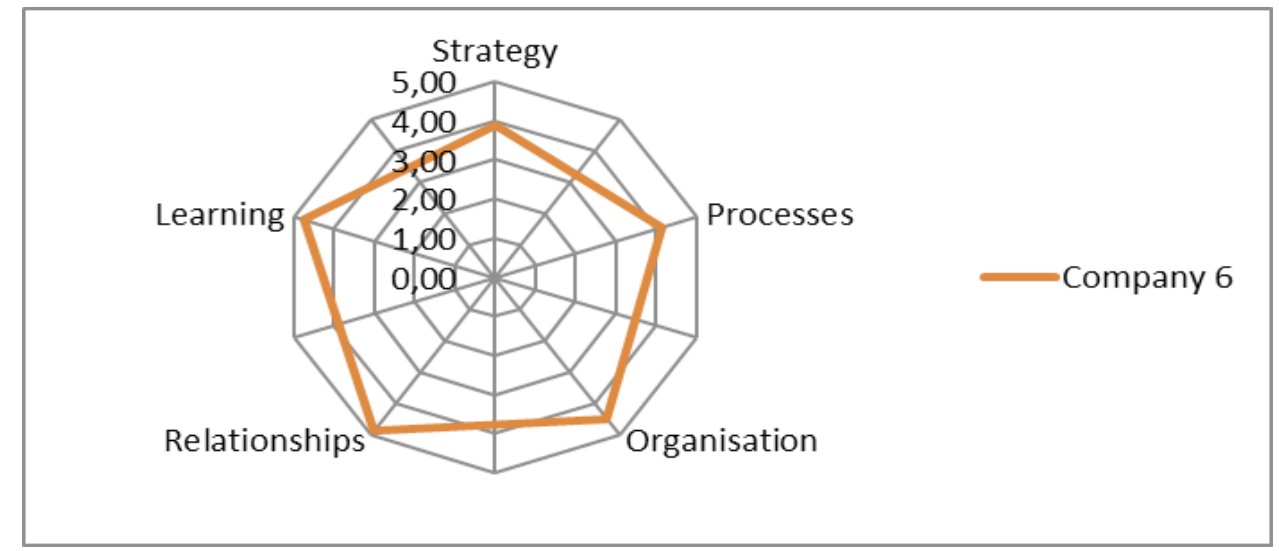

Fig. 6. Company 6 data

Source: Survey data (2016)

Company 7 presents similar results than Company 6, with an average of four in four factors: processes, organisation, relationships and learning. The company averaged 3.50 on strategy or $50 \%$ of effectiveness. It demonstrates the lack of attention and no clear innovation strategy, since not everyone in the organisation are aware of what the company wants (Figure 7).

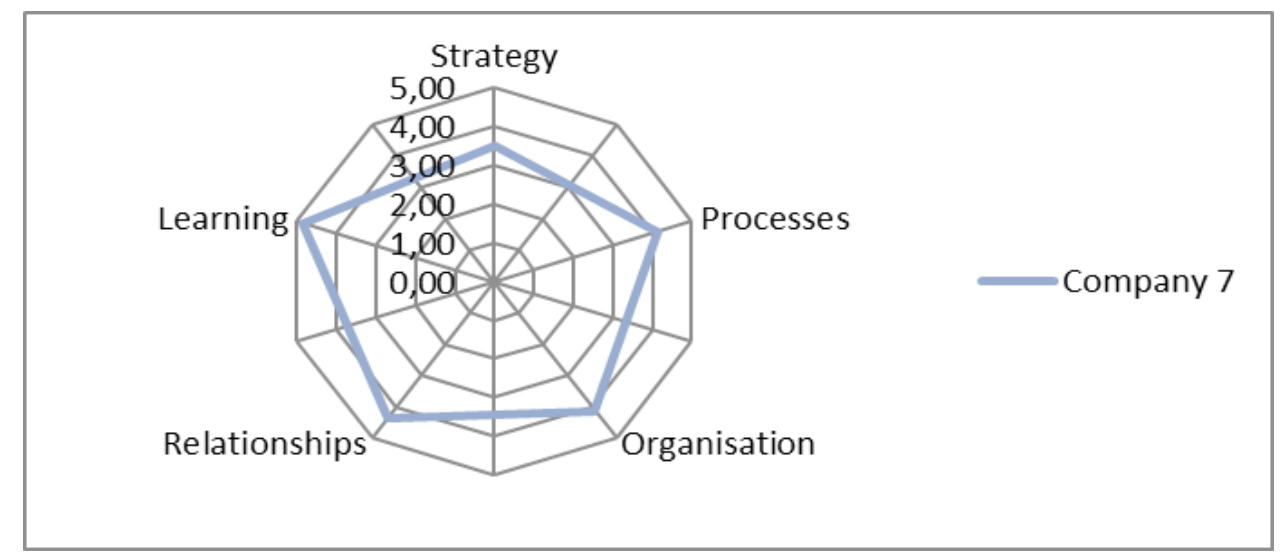

Fig. 7. Company 7 data

Source: Survey data (2016) 
Company 8 shows average in strategy, process and organisation of 3,00, corresponding to an effectiveness of $42.86 \%$, the lowest of all surveyed averages. This shows that the company needs to review the product development plan, as well as the internal organisation of the company.

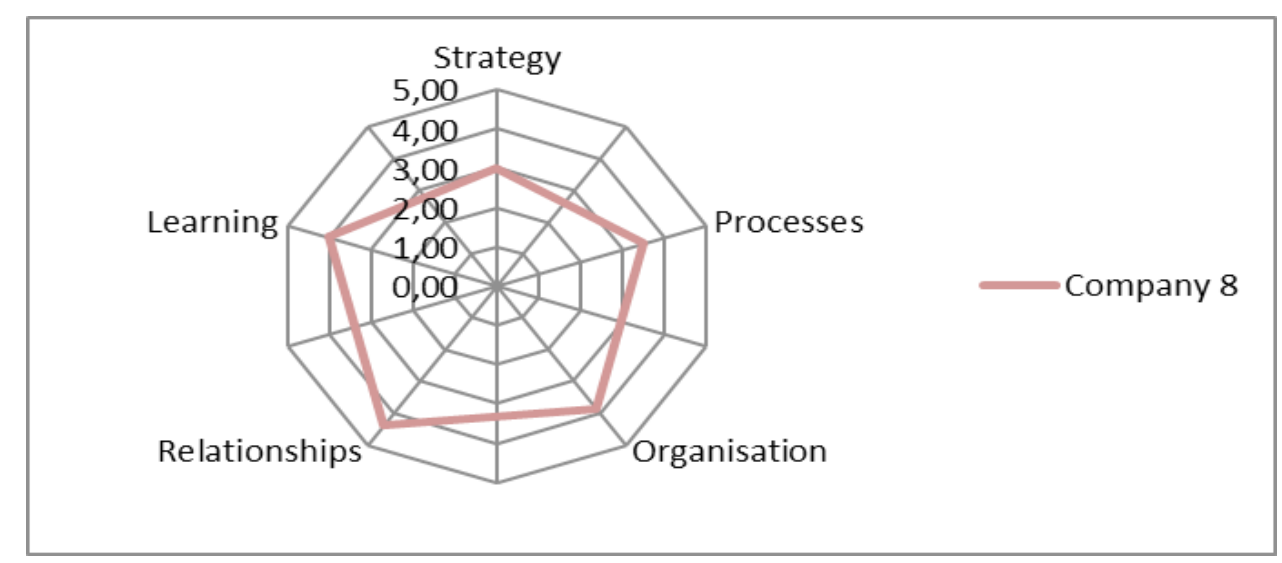

Fig. 8. Company 8 data

Source: Survey data (2016)

In the group of companies analyzed, the most innovative company is Company 1, with a final average of all the factors in 5.08. However, the company with the lowest average was the Company 8, with 3.75 , making it the least innovative company.

From this data, the results show that the strategy factor is less implemented than the others, corresponding to a $56.86 \%$ of effectiveness. The "relationships" factor presents the highest average of $69.71 \%$, followed by the concept of "learning" with $66.57 \%$ and the concept of "organisation", represented with a result of $62.71 \%$. It is important to note that companies need to spend more attention on the process factor because they are more effective in generating successful development, organizational goals and objectives, and development of new products.

Figure 9 shows all surveyed companies' data.

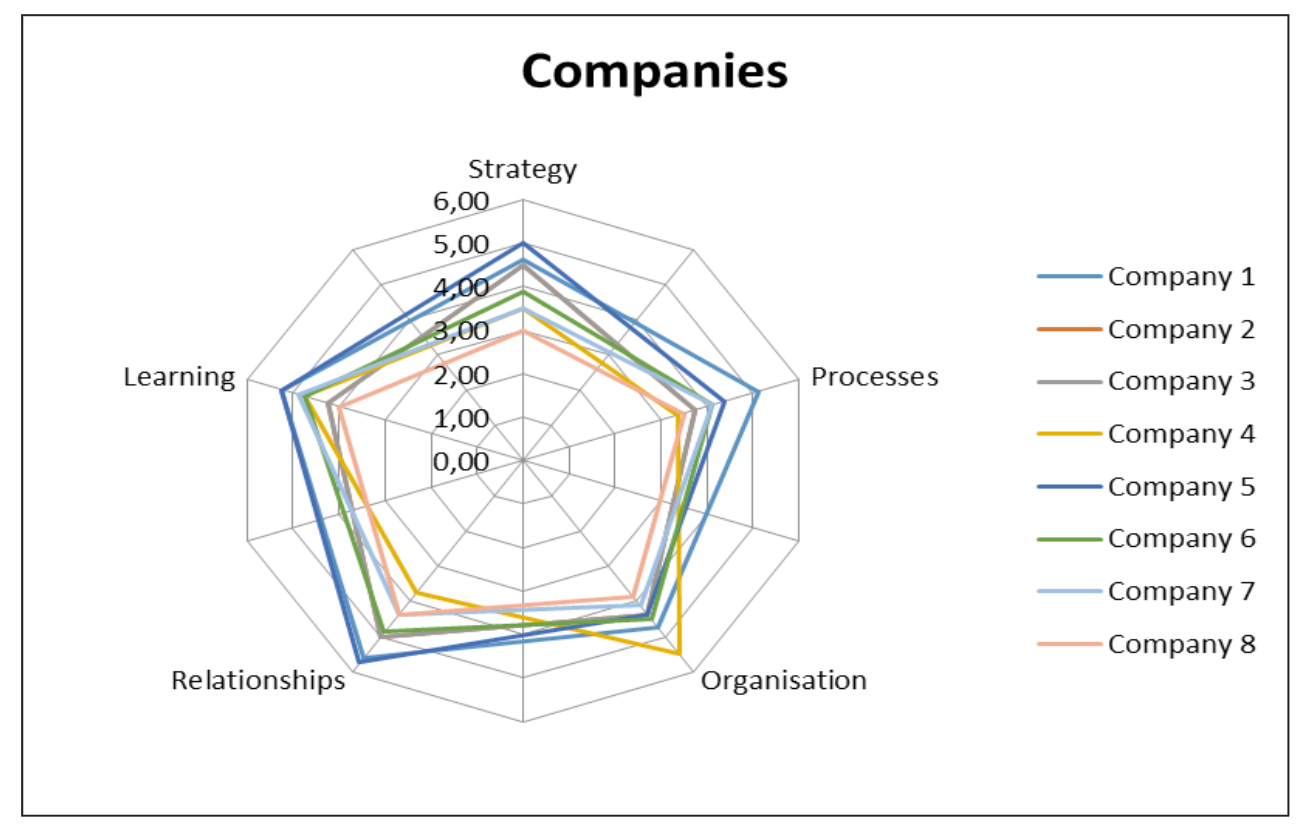

Fig. 9. Innovation Radar in PEPI Companies

Source: Survey data (2016) 4.1 Empirical model indicators 
The empirical model indicators presents a systemic understanding of the competitiveness of two specific elements identified in the radar model: relationship with a result of 4.88 and learning with 4.66. Low results from the strategy (3.98), the process (4.03) and the organisation (4.39) indicators suggest their presence in the companies. In the model, a logical configuration for such an embodiment is also proposed, as shown in figure 10, in steps 1,2 and 3.

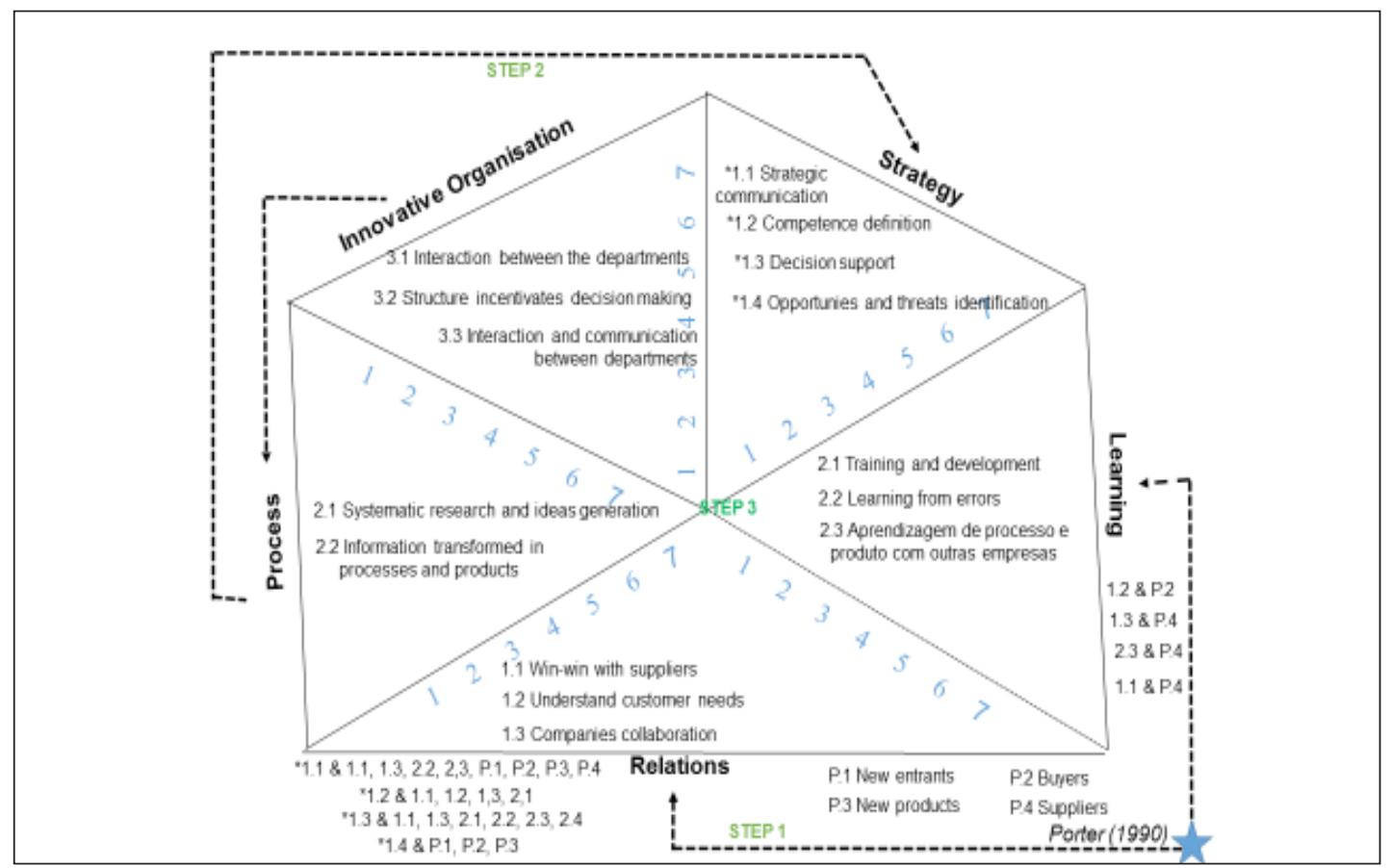

Fig. 10. Optimization of the innovation radar variables Source: Elaborated by the authors (2018)

In order to be related to the external environment, the matrix of Porter (1990) was inserted in the logic comparing these elements with the analysis theory of industries and competitive positioning, represented pro: P1 new entrants, P2 buyers, P3 new products and P4 suppliers. According to step 1, it was primarily identified that the "relationship" indicator of the companies presented the highest index, followed by the "learning" factor. The relationship item is linked to a win-win relationship with suppliers, in understanding customer needs and collaborations with other companies. The concept of "learning" characterizes the capacity of the organisation, training and development, learning by errors and, processes and products development with other companies. The analysis through the concepts of Porter (1990), from the identified collective competencies, represented by the concepts of "relationship" and "learning", the following configuration arises in view of competitive expansion: 1.1 \& P.4; 1.2 \& P.2; 2.3 \& P.4 and 1.3 \& P.1.

The $1.1 \&$ P.4 configuration shows the importance to maintain the "competence - win-win relationship" between companies and suppliers, in order to foster learning. The development of $1.2 \&$ P. 2 enhances the understanding of the need of customers in the competitive market, and suggests the increase in the barriers to entry of new entrants to reduce competitive intensity. For the $2.3 \&$ P4 relationship, the learning processes and products from other companies and suppliers makes the whole segment evolve. In the item $1.3 \& \mathrm{P} 1$, collaboration with companies as well as suppliers could be developed with the new entrants in the market, by taking advantage of the flexibility and the originality of these organisations. It could, in turn, increase both learning and strategic relationships. 
Stage 2 includes the evolution of the elements identified in the model that have the lowest indexes: strategy, processes and organisation, with 3.98, 4.03 and 4.39 as a result. Initially it is understood that for the development of a full strategy, according to items $* 1.1, * 1.2, * 1.3$ and $* 1.4$, it is necessary to restructure the companies from the point of view of the "organisation" and "process" variables. Then, through the item "organisation", it could represents the creation and the proposal of a change of structural morphology, by creating and proposing a horizontal type structure. Such initiative would favor the establishment of organizational decision process (3.2), the increase in the interaction between the departments (3.1) and the communication between departments (3.3). The restructuring of an organisation enhances the maximization of its processes, related to the systematic identification of ideas (2.1), and transforming them into processes and products. Thus, such pattern would enhances the establishment of new organizational strategies.

The expansion of the radar variables in competitiveness will impact on the "learning" and "relationship" variables. Based on the Porter (1990) analysis and according to STEP 1, the proposed improvements to increase the degree of the "organisation" and "process" variables in STEP 2 to execute the strategy proceed to STEP 3 , where the elements of this variable are logically related to the variables of STEP 1 . The relation * $1.4 \&$ P.1, P. 2 and P.3 promote the identification of opportunities and needs -*1,4 enhances the anticipation of the new entrants P.1 and the identification of the needs of the buyer P.2, and by protecting the company from the entrance of new products P.3. In the relation $* 1.2 \& 1.1,1.2,1.3,2.1$, when defining competence $* 1.2$, it is feasible to establish both collaborations and relationship with the other companies 1.2 and 1.3 , as well as to promote training and development.

In this sense, there is the cynetic effect of competence, making it strategic in relation to the other actors. The structure $* 1,3 \& 1.1,1.3,2.1,2.2,2.3,2.4$, through the support of the decision-makers $* 1.3$, it is possible to realize a cooperation with the other companies of segment 1.1 and 1.3 , by taking advantage of the generation of training and development (2.1). It is still relevant since the support of the decision-making comes from a "learning with errors" culture (2.2) that becomes, in effect, a continuous learning process and product with the other companies (2.4). The relation *1.1 \& 1.1, 1.3, P.1, P.2, P.3, P.4, 2.2 and 2.3 is based on the premise that by communicating the strategy, it is possible to generate strategic alignment with other actors (1.1 and 1.3), which would neutralize and influence the organisation of the bargaining power of new entrants, buyers, substitutes and suppliers, which is typical for an "outside-in strategy". The communication of the strategy will also have a positive influence on the processes, creating a learning with the errors culture (2.2), eventually changing routines and products through learning (2.3).

\section{Conclusions}

The results of this study emphasizes the importance of innovation management in the organisations, making this a differentiating factor tool for competitiveness in view of the explanation of subjective elements that form the basis of innovation and strategy, learning, relationships, processes and organisation. Through the survey of the companies participating in the study, it was found that the issues surrounding "innovation management" are embedded in business routines. A strategic perspective allows a more delimited and focus path of actions which allows more transparency within the organisation. Such pattern impacts directly on innovation management and on its hability to be measured.

By analyzing the results obtained from the survey along the eight participating companies, it appears that all of them manage the five factors identified in the data collection instrument, namely, strategy, learning, 
processes, relationships and organisation. However, most needs to improve its management to achieve goals. Therefore, the objective of this work was to identify the degree of innovation of organisations selected from the productive extension design and innovation of the Rio Grande do Sul State through the application of an audit of innovation, has been achieved. Reaching the conclusion that companies need to review how they are working to innovation management, since from it you can diagnose actions and design goals for process improvement.

The research limitations highlight the number of companies surveyed. More participants would allow a better panorama on innovation from the sector. Future researches could include expanded samples or applications to others sectors of the economy.

\section{References}

Ahlstrand, B., Lampel, J., \& Mintzberg, H. (2001). Strategy Safari: A Guided Tour Through The Wilds of Strategic Management. New York: Simon and Schuster Publishing.

Ansoff, H. I. (1990). Administração estratégica. São Paulo: Atlas.

Ansoff, I. H. Declerck, P. R., \& Hayes, L. R. (1990). Do Planejamento Estratégico a Administração Estratégica. São Paulo: Atlas.

Baggio, D., Wegner, D., \& Dalmarco, G. (2018). Coordination Mechanisms of Collaborative R\&D Projects in Small and Medium Enterprises. RAM, Rev. Adm. Mackenzie. 19 (2), 1-27.

Ballou, H. R. (2006). Gerenciamento da cadeia de suprimentos/logística empresarial. 5 ed. Porto Alegre: Bookman.

Batraga, A., Salkovska, J., Braslina, L., Legzdina, A., \& Kalkis, H. (2019). New innovation identification approach development matrix. Advances in Intelligent Systems and Computing.783, 261-273.

Betim, L. M., Resende, L. M., Andrade Junior, P. P. Pontes, J., \& Petter, R. R. H. (2018). Relações verticais e horizontais no processo de inovação e aprendizagem interativa: estudo em um aglomerado produtivo. Gestão \& Produção. 1-14.

Carona, M. N., \& Csillag, M. J. (2006). Desenvolvimento e manutenção de relacionamentos em redes de suprimentos. In: Encontro Anual da ANPAD, 2006. Salvador. Anais... Salvador: Anpad, 1-13.

De Prato, G., Nepelski, D., \& Piroli, G. (2015). Innovation Radar: Identifying Innovations and Innovators with High Potential in ICT FP7, CIP \& H2020 Projects. JRC Scientific and Policy Reports - EUR 27314 EN. Seville: JRC-IPTS.

Drucker, P. F. (1999). Sociedade pós-capitalista. São Paulo: Pioneira. 
Fan, C. S., Tsai, S. F., \& Lin, L. J. (2010). Leveraging tenant-incubator social capital for organizational learning and performance in incubation programme. International Small Business Journal. 28, 90-113.

Gibbs, G. R. (2009). Análise de dados qualitativos. Porto Alegre: Bookman.

Governo do Estado do Rio Grande do Sul. (2015). Manual do Extensionista: Projeto Extensão Produtiva e Inovação. 3 ed. Porto Alegre.

Grant, M. R. (1996). Toward a Knowledge-Based Theory Of The Firm. Strategic Management Journal. 17 (Special Issue: Knowledge and the Firm) 109-122.

Grönroos, C. (2000). Relationship marketing: the nordic school perspective. In. Sheth, J. N., \& Parvatiyar, A. (eds). Handbook of relationship marketing. Thousand Oaks: Sage Publications, 95-117.

Hax, C. A., \& Majluf, S. N. (1986). Strategy and the strategy formation process. Sloan School of Management-MIT.

Humphrey, J., \& Schmitz, H. (2000). Governance and upgrading: linking industrial cluster and global value chain research. IDS Working Paper 120, Institute of Development Studies University of Sussex, 2000.

Hitt, A. M., Ireland, R. D., \& Hoskisson, R. (2002). Administração estratégica. São Paulo: Pioneira Thomson Learning.

Johannessen, A, J. (2013). Innovation: a systemic perspective - developing a systemic innovation theory. Kybernetes. 42 (8) 1195-1217.

Lundvall, B., \& Johnson, B. (2000). Promoting innovation systems as a response to the globalising learning economy. Rio de Janeiro: Instituto de Economia, Universidade Federal do Rio de Janeiro.

Maximiano, A. C. A. (2012). Teoria Geral da Administração: da revolução urbana à revolução digital. 7 ed. São Paulo: Atlas.

Mintzberg H. (1989). The Structuring of Organizations. In: Asch D., Bowman C. (eds) Readings in Strategic Management. Palgrave, London.

Nonaka, I., \& Takeuchi, H. (1995). The knowledge-creating company: How Japanese companies create the dynamics of innovation. New York: Oxford University Press.

Nonaka, I., \& Toyama, R. (2002). A firm as a dialectical being: towards a dynamic theory of a firm. Industrial and Corporate Change. 11(5), 995-1009. 
OECD. (2005). Oslo Manual. The measurement of scientific and technological activities.

Pereira, R. C. F. (2004). Redes de empresas e marketing de relacionamento: convergências e desdobramentos competitivos. In: Slongo, L. A., \& Liberali, G. (org.). Marketing de relacionamento: estudos, cases e proposições de pesquisa. São Paulo: Atlas.

Pestana, M. H., \& Gageiro, J. N. (2005). Análise de dados para ciências sociais: a complementariedade do SPSS. 4 ed. rev. e aum. Lisboa, Portugal: Sílabo.

Porter, M. (1990). Competitive Advantage of Nations: Creating and Sustaining Superior Performance. New York: The Free Press.

Prajogo, D., Toy, J., Bhattacharya, A., Oke, A., \& Cheng, T. C. E. (2018). The relationships between information management, process management and operational performance: Internal and external contexts. International Journal of Production Economics. 199, 95-103.

Resende, V. T. P., Mendonça, D. G., \& Araújo, B. B. (2005). Estratégias de formação de ambientes colaborativos com fornecedores no gerenciamento de cadeias de suprimentos no Brasil. In: Encontro Anual da ANPAD, 2005. Brasília. Anais... Rio de Janeiro: Anpad.

Sampieri, R. H., Collado, C. F., \& Lucio, P. B. (1998). Metodología de la investigación. México: McGrawHill.

Schumpeter, J. (1997). Teoria do Desenvolvimento Econômico. Uma investigação sobre lucros, capital, crédito, juros e o ciclo econômico. São Paulo: Editora Nova Cultura.

Spender, J. C. (1996). Making knowledge the basis of a dynamic theory of the firm. Strategic Management Journal. 17 (Winter Special Issue), 45-62.

Steensen, E. F. (2014). Five types of organizational strategy. Scandinavian Journal of Management. 30, 266281.

Teece, D. J. (2010). Business Models, Business Strategy and Innovation. Long Range Planning. 43, 172-194.

Tidd, J., Bessant, J,. \& Pavitt, K. (2008). Gestão da inovação. 3 ed. Porto Alegre: Bookman.

UPF - Universidade de Passo Fundo. [online] http://www.upf.br/site/index.php?option=com_content\&task=view\&id=2\&Itemid=3\#.VrEQZLIrLIU (Accessed on 02 February 2015). 
UPFTEC - Divisão de Intercâmbio em Ciência e Tecnologia da Universidade de Passo Fundo. [online] http:// www.upf.br/upftec/index.php?option=com_content\&view=article\&id=15\&Itemid=20.

(Accessed 02 February 2015).

Volberda, H. (2004). Crise em Estratégia: Fragmentação, Integração ou Síntese. Revista de Administração de Empresa-RAE. 44(4), 32-43.

Whitley, R. (2000). The institutional structuring of innovation strategies: business systems, firm types and patterns of technical change in different market economies. Organization studies. 21(25), 855-886. 